\title{
Bioremediation of Endosulfan Contaminated Soil by using Microbial Consortia in the Field
}

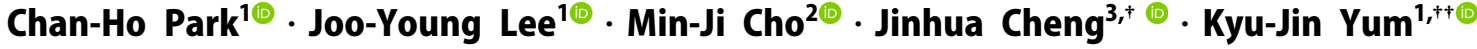 \\ ${ }^{1}$ Coenbio Co., Ltd. \\ ${ }^{2}$ Department of Interdisciplinary Program of Biomodulation, Myongji University \\ ${ }^{3}$ Center for Neutraceutical and Pharmaceutical Materials, Myongji University
}

(Received October 15, 2020; Revised November 12, 2020; Accepted November 18, 2020)

Objectives: The use of risky and persistent organochlorine pesticides was prohibited, but is still detected in many agricultural lands. In this study, Phanerochaete chrysosporium Y-2 (KCCM-10725P) and Streptomyces sp. MJM14747 (KACC 81078BP), which were finally selected among various candidate microorganisms, were applied to field soil and estimated the endosulfan removal rate.

Methods: The field testing sites were set to an area of $3 \mathrm{~m} \times 3 \mathrm{~m}$, respectively. A $35 \%$ endosulfan emulsion was sprayed on both sites so that the final concentration was about $20 \mu \mathrm{g} / \mathrm{g}$. Thereafter, $12 \mathrm{~kg}$ of original sawdust and $12 \mathrm{~kg}$ of sawdust loaded with microbial consortia were mixed at each of the two sites. During the test period for a total of 100 days, samples were taken every 30 days. Soil samples were extracted according to the QuEChERS AOAC method and analyzed by gas chromatography.

Results and Discussion: The concentrations immediately after endosulfan emulsion treatment at both sites were detected as $21.2 \mu \mathrm{g} / \mathrm{g}$ and $21.9 \mu \mathrm{g} / \mathrm{g}$, respectively. The removal rate of endosulfan at the site without microbial consortia treatment (Control) was about $21.9 \%$ until the 30 th day, and $54.4 \%$ on the 100th day. On the other hand, the endosulfan removal rate on the 100th day of the site treated with microbial consortia was $89.5 \%$, which was 1.6 times higher than that of the control site. On the 30 th day, the removal rate was $56.8 \%$, and the rate of degradation of endosulfan increased thereafter. Among the major components of endosulfan, the removal rate of a -endosulfan was higher than that of $\beta$-endosulfan. After 100 days, the removal rates of $\alpha$-endosulfan and $\beta$ -endosulfan were $98.0 \%$ and $83.5 \%$, respectively.

Conclusions: Streptomyces sp. MJM14747 showed good degradation ability in the presence of endosulfan at a high concentration of around $100 \mu \mathrm{g} / \mathrm{g}$. Moreover, Phanerochaete chrysosporium Y-2 has a good performance in the removal of $\beta$-endosulfan, which is slow degrading components of endosulfan. Microbial consortia are expected to be applied not only to domestic and foreign agricultural land but also to overall bioremediation projects.

Keywords : Organochlorine Pesticide, Endosulfan, Microbial Consortia, Bioremediation

The Korean text of this paper can be translated into multiple languages on the website of http://jksee.or.kr through Google Translator. 


\title{
연구논문
}

\section{Endosulfan으로 오염된 현장토양의 복합미생물제제를 이용한 생물학적 정화}

\author{
박찬호 $^{1 \oplus} \cdot$ 이주영 $^{1 \odot} \cdot$ 조민지 $^{2 \oplus} \cdot$ 성금화 $^{3,+} \odot \cdot$ 염규진 $^{1,++}$ \\ ${ }^{1}$ 주식회사 코엔바이오 \\ ${ }^{2}$ 명지대학교 바이오모듈레이션학과 \\ ${ }^{3}$ 명지대학교 농생명바이오식의약소재개발사업단
}

목적: 잔류성 유기염소계 농약의 사용은 금지 되었지만 여전히 많은 농경지에서 검출되고 있다. 본 연구에서는 다 양한 후보 미생물 중에서 최종 선발된 Phanerochaete chrysosporium Y-2 (KCCM-10725P) 및 Streptomyces sp. MJM14747 (KACC 81078BP) 균주를 복합미생물 형태로 현장토양에 적용하여 endosulfan 제거율을 평가하였다.

방법: 현장 시험용 부지는 대조구 및 시험구로 각각 $3 \mathrm{~m} \times 3 \mathrm{~m}$ 면적으로 설정하였다. 두 site에 $35 \%$ endosulfan 유제를 살포하여 최종 농도가 약 $20 \mu \mathrm{g} / \mathrm{g}$ 이 되도록 하였다. 그 후 아무 처리를 하지 않은 톱밥 $12 \mathrm{~kg}$ 및 복합미생 물이 담지된 톱밥 $12 \mathrm{~kg}$ 을 두 site 토양에 각각 혼합하였다. 총 100 일 동안의 실험 기간 중 시료는 30 일 단위로 채 취하였다. 채취된 토양 시료는 $\mathrm{QuEChERS} \mathrm{AOAC} \mathrm{방법에} \mathrm{따라} \mathrm{추출} \mathrm{및} \mathrm{전처리하였고} \mathrm{gas} \mathrm{chromatography로} \mathrm{분석}$ 하였다.

결과 및 토의: 대조구 및 실험구에 endosulfan 유제를 처리한 직후의 농도는 각각 $21.2 \mu \mathrm{g} / \mathrm{g}$ 및 $21.9 \mu \mathrm{g} / \mathrm{g}$ 으로 분석 되었다. 미생물을 처리하지 않은 대조구 사이트의 endosulfan 제거율은 30 일까지 약 $21.9 \%$ 를 나타냈고, 100 일째 에는 $54.4 \%$ 를 나타냈다. 반면, 복합미생물을 처리한 사이트의 100 일째 endosulfan 제거율은 $89.5 \%$ 로 대조구에 비하여 1.6 배 높게 나타났다. 30 일째의 제거율은 $56.8 \%$ 였고 이후 endosulfan의 제거율이 빠르게 증가하는 경향 을 보였다. Endosulfan의 주요 성분 중 a-endosulfan의 제거율이 $\beta$-endosulfan보다 높게 나타났다. 100 일 경과 시 a-endosulfan과 $\beta$-endosulfan의 제거율은 각각 $98.0 \%$ 및 $83.5 \%$ 로 확인되었다.

결론: 미생물복합제제로 선발된 Streptomyces sp. MJM14747은 $100 \mu \mathrm{g} / \mathrm{g}$ 내외의 고농도 endosulfan 존재하에서도 분해능이 우수하였고, Phanerochaete chrysosporium Y-2은 endosulfan의 분해속도가 느린 $\beta$-endosulfan의 제거에 우 수하였다. 복합미생물제제는 앞으로 잔류농약 문제에 직면해 있는 국내외 농경지 토양뿐만 아니라 생물학적 정화 사업 전반에 응용 가능할 것으로 기대된다.

주제어 : 유기염소계농약, 엔도설판, 복합미생물, 생물정화법

\section{1. 서론}

유기염소계 살충제인 $\mathrm{BHC}, \mathrm{DDT}$, endosulfan, heptachlor, aldrin 등은 병충해로부터 농작물을 보호하기 위하여 광범위 하게 사용되었다. ${ }^{1)}$ 그중 endosulfan은 높은 독성, 생물 농축 성, 이동성, 난분해성 등의 특징이 있는 것으로 알려져 있으 며 특히 어류, 무척추동물, 포유류에 유전독성 및 신경독성 을 유발할 수 있고 반감기 또한 60-800일로 길어 위험한 살 충제로 보고되고 있다. ${ }^{2,3)}$ 그러나 아시아의 개발도상국, 인 도 및 중국에서는 여전히 사용되고 있으며 토양, 대기, 수계 등 다양한 환경에서 검출되고 있다. ${ }^{4,5)}$ 우리나라에서는 2011
년부터 endosulfan의 농약 등록이 취소되었고, 2015년부터 는 잔류성유기오염물질에 포함시켜 관리를 강화하고 있다. ${ }^{6}$ 그러나 endosulfan의 국내 사용이 전면 중단되었음에도 불 구하고 시설재배지 및 밭 토양 등의 농업환경 및 농작물에 서 현재까지 검출되고 있다. ${ }^{7)}$ Endosulfan이 허용기준을 초 과하여 검출되는 경우는 흔하지 않으나 환경 및 인간에게 미치는 만성적인 영향을 고려한다면 무독화 방안 및 환경 복원 기술의 개발이 필요하다. ${ }^{8)}$ 무독화 방법 중에서 미생물 을 이용한 bioremediaton 기술은 화학적 처리 방법에 비하 여 2차 오염의 우려가 없고 환경학적 안전성, 경제성, 작업 의 간편성, 고효율 및 광역적 적용이 가능하다는 장점이 있 
다. ${ }^{9-11)}$ 국내에서는 신재호 등리이 endosulfan을 미생물학적 으로 처리하기 위한 기초단계의 연구로 Bacillus sp. E64-2 균주를 사용하여 연구실 내 조건에서 진행한 바 있고, 조민 섭 등 ${ }^{13)}$ 은 활성탄에 Klebsiella oxytoca KE-8 균주를 담지 후 endosulfan 분해능 시험을 연구실 내에서 진행한 바 있 다. 국외에서는 Ishag 등 ${ }^{14)}$ 이 살충제로 오염된 토양에서 후 보 균주를 선발하여 endosulfan 분해에 대한 연구를 연구실 에서 진행한 바 있고, Shivaramaiah 등 ${ }^{15)}$ 또한 토양에 존재 하는 토착 세균을 이용하여 분해실험을 진행하였다.

본 연구에서는 국내 농경지 토양에서 분리한 후보 미생물 을 실험실 조건에서 분석 후 그 중 endosulfan 분해능이 가장 우수하였던 곰팡이 1종(Phanerochaete chrysosporium Y-2 (KCCM-10725P)) 및 방선균 1종(Streptomyces sp. MJM14747 (KACC 81078BP))을 최종 선발하였으며, endosulfan 분해에 가장 적합한 복합미생물 형태로 제조하여 현장 시험을 진행 하였다. 복합미생물제제용 담체는 사용 미생물의 형태적, 생 물학적 특성을 고려하여 선발하였다. 미생물 담체의 종류는 제올라이트, 세라믹, 활성탄 및 폴리우레탄 등 여러 가지가 관련 산업에 사용되고 있으나 토양에 미생물을 처리하기 위 해서는 특별한 담체의 선발이 필요하였다. 본 현장토양 실험 에 사용되는 미생물은 곰팡이 및 방선균으로 이 두 미생물은 형태적으로 모두 균사를 형성하는 특성이 있고 증식이 되면 육안으로 보일 정도로 세포의 크기가 크다. 따라서 균사 형태 의 큰 세포를 가지는 미생물을 담지할 수 있는 담체가 필요하 였다. 더불어 복원 이후 농사를 짓는 토양의 경우 작물을 경작할 수 있는 원래의 기능을 유지해야 하기 때문에 세라 믹 담체보다는 자연적으로 분해가 가능한 유기물 담체를 선 정하는데 주안점을 두었다. 유기물 담체로는 왕겨 또는 톱 밥을 후보로 두었으나 왕겨는 자연 분해 기간이 비교적 긴 단점이 있어 톱밥을 최종 유기물 담체로 선발하였다. 현장 토양 실험에 사용되는 미생물 중 P. chrysosporium Y-2는 백 색부후균으로 리그닌을 분해하여 영양원으로 사용하는 곰 팡이다. 따라서 톱밥은 P. chrysosporium $\mathrm{Y}-2$ 의 담체화 증식 에 유리할 것으로 기대되었고 톱밥의 표면이 거칠어 곰팡이 및 방선균과 같은 사상성 균사 형태의 미생물의 부착에 적 합하며, 비용 또한 매우 저렴하여 경제성에서도 우수한 담체 로 판단하였다. 현장 시험은 비닐하우스 내 토양에 인위적으 로 endosulfan 유제를 오염시킨 후 선발된 복합미생물을 처리 하여 총 100 일 동안 진행하였으며, 30 일 단위로 시료를 채취 하여 잔류하는 endosulfan을 분석하였다.

\section{2. 재료 및 방법}

\subsection{Endosulfan 분해능이 우수한 미생물의 선발}

Endosulfan 분해능이 우수한 균주를 선발하기 위해 명지대 학교에서 1차 선발한 방선균 3종(Streptomyces sp. MJM14731,
Streptomyces sp. MJM14747, Streptomyces sp. MJM14850) 과 자사보유 미생물 2종(Phanerochaete chrysosporium Y-2, Trichosporon loubieri $\mathrm{Y}-1 \mathrm{~A})$ 에 대하여 실험실 조건에서 토 양 실험을 진행하였다. ${ }^{16,17)}$ 방선균 3종은 Barnnett's medium 에 각각 접종하여 $30^{\circ} \mathrm{C} / 130 \mathrm{rpm}$ 조건에서 7일간 배양하였 다. 곰팡이인 P. chrysosporium Y-2는 $\mathrm{PDB}$ 배지에 접종하여 $30^{\circ} \mathrm{C} / 120 \mathrm{rpm}$ 조건에서 72 시간 배양하였고, 효모인 $T$. loubieri $\mathrm{Y}-1 \mathrm{~A}$ 는 YPD 배지에 접종하여 $25^{\circ} \mathrm{C} / 120 \mathrm{rpm}$ 조건 에서 48 시간 배양하였다. 배양된 미생물은 $3,000 \mathrm{rpm} / 10$ $\mathrm{min}$ 동안 원심분리하여 상등액은 버리고 cell만 확보하였다. 실험에 사용된 cell량 측정은 원심분리 후 상등액을 제거한 직후의 습중량으로 하였다. 실험용 토양으로는 시판되는 조 경용 황토를 사용하였고, 사용 전에 $425 \mu \mathrm{m}$ (No. 40) mesh 로 거른 후 $121^{\circ} \mathrm{C} / 30 \mathrm{~min}$ 멸균, 방냉, 하루 방치 및 재멸균 하는 간헐멸균 과정을 거쳐 토양 내 잔존 가능한 미생물 및 포자를 사멸하였다. 그 후 $60^{\circ} \mathrm{C}$ 건조기에 24 시간 건조 후 실험에 사용하였다.

총 5 종 미생물의 endosulfan 독성 내성 및 분해율 차이를 명확히 하기 위하여 토양에 endosulfan 유제를 처리한 이후 의 최종 농도를 $138 \mu \mathrm{g} / \mathrm{g}$ 이 되도록 하였다. 유제가 처리된 토양 $20 \mathrm{~g}$ 에 각각의 미생물을 습중량으로 $0.2 \mathrm{~g}$ 씩 처리하여 균질화하였으며, 실험조건별로 3 개씩 처리하여 3 반복 실험 하였다. Endosulfan으로 오염된 토양에 미생물을 접종 후 방 선균 및 효모는 $25^{\circ} \mathrm{C}$, 곰팡이는 $30^{\circ} \mathrm{C}$ 배양기에 넣고 습도를 약 70-80\%로 유지시키며 5일 단위로 약 $2 \mathrm{~g}$ 의 시료를 채취 하여 총 20 일간 실험을 진행하였다. 채취된 시료는 2 일 동 안 음건 후 정확한 무게를 칭량하여 GC-ECD 분석용 시료 로 사용하였다.

\section{2. 최종 선발된 복합미생물의 endosulfan 분해능}

토양 중 endosulfan 농도가 약 $138 \mu \mathrm{g} / \mathrm{g}$ 일 때 방선균, 곰 팡이, 효모 중 endosulfan 분해능이 우수하였던 균주 2종에 대하여 두 미생물을 특정 비율로 혼합 적용 시 endosulfan 분해능이 개선되는지 여부를 확인하고자 실험실 조건에서 토양 실험을 진행하였다. 미생물의 배양조건, cell 분리 과 정, 토양 전처리 과정은 2.1 에 기술한 내용과 동일하며, 고 농도 endosulfan 환경과 달리 저농도에서 미생물 처리 조건 에 따른 분해능 차이를 확인하기 위하여 endosulfan 처리 농 도를 $22.7 \mu \mathrm{g} / \mathrm{g}$ 으로 낮춰 실험을 진행하였다. 특히, 주요 성 분인 a-endosulfan 및 $\beta$-endosulfan의 농도를 동일하게 맞추 기 위하여 $\beta$-endosulfan 표준품을 추가로 사용하였다. 일반 적으로 $\alpha$-endosulfan보다 $\beta$-endosulfan의 분해 진행속도가 느리게 나타나 동일한 농도일 때 두 물질의 분해 정도의 차 이를 비교하고자 하였다. 유제가 처리된 토양 $20 \mathrm{~g}$ 에 각각의 비율로 혼합된 미생물을(100:0, 30:70, 50:50, 70:30, 0:100) 습중량으로 $0.2 \mathrm{~g}$ 넣은 후 균질화하였다. 실험조건별로 3 개 
Table 1. Instrumental conditions for residual endosulfan in soil.

\begin{tabular}{|c|c|c|c|c|}
\hline Items & \multicolumn{4}{|c|}{ Instrumental conditions } \\
\hline Column & \multicolumn{4}{|c|}{ DB-5MSD Agilent Tech. $30 \mathrm{~m} \times 0.25 \mathrm{~mm}, 0.25 \mu \mathrm{M}$} \\
\hline Carrier gas & \multicolumn{4}{|c|}{$\mathrm{He}(1 \mathrm{~mL} / \mathrm{min})$} \\
\hline Injection volume & \multicolumn{4}{|c|}{$1 \mu \mathrm{L}$} \\
\hline Injection mode & \multicolumn{4}{|c|}{ Split } \\
\hline Inlet temperature & \multicolumn{4}{|c|}{$250^{\circ} \mathrm{C}$} \\
\hline Detector temperature & \multicolumn{4}{|c|}{$300^{\circ} \mathrm{C}$} \\
\hline \multirow{4}{*}{ Oven temperature } & Stage & Rate $\left({ }^{\circ} \mathrm{C} / \mathrm{min}\right)$ & Temperature $\left({ }^{\circ} \mathrm{C}\right)$ & Hold time (min) \\
\hline & Initial & 0 & 140 & 0 \\
\hline & Ramp 1 & 8 & 180 & 1 \\
\hline & Ramp 2 & 4 & 250 & 16.5 \\
\hline
\end{tabular}

씩 처리하여 3 반복 실험하였으며, 이후 실온에서 배양하였 고, 실험 기간, 시료 채취, 분석을 위한 전처리 과정은 2.1 에 기술한 방법과 동일하게 진행하였다.

\section{3. 시약 및 표준품}

시험 토양 중 유기염소계농약인 endosulfan 잔류량을 분 석하기 위하여 a-endosulfan, $\beta$-endosulfan 및 endosulfan sulfate는 Wako Pure Chemical Industries (Osaka, Japan)에서 구입하였고, endosulfan diol, endosulfan ether 및 lactone은 Dr. Ehrenstorfer GmbH (Augsburg, Germany)에서 구입하였다.

\subsection{Endosulfan 분석}

\subsection{1. 실험실 토양 시료}

토양 중 endosulfan의 분석은 Restek사의 QuEChERS kit (Pennsylvania, USA)를 사용하였으며, AOAC 2007 방법을 ${ }^{18)}$ 일부 수정하여 토양 $1.5 \mathrm{~g}$ 에 acetone $4 \mathrm{~mL}$ 를 가한 후 $150 \mathrm{rpm}$ 으로 2 시간 진탕 및 추출하였다. Acetone 추출액은 $0.45 \mu \mathrm{m}$ syringe filter로 여과 후 질소가스를 이용하여 $3 \mathrm{~mL}$ 로 농축하 였다. 이 중 $1.5 \mathrm{~mL}$ 를 취하여 magnesium sulfate $150 \mathrm{mg}$, primary secondary amine (PSA) $50 \mathrm{mg}$ 을 포함한 $2 \mathrm{~mL}$ 용량 의 QuEChERS dSPE tube에 넣고 Vortex mixer를 이용하여 5 분간 진탕한 다음 원심분리(3,000 rpm/10 min)하고, 상등액 을 syringe filter $(0.22 \mu \mathrm{m})$ 로 여과한 후 gas chromatography (GC, Agilent Technologies, Santa Clara, USA) GC-ECD를 이 용하여 Table 1 의 기기 조건에서 분석하였다.

\subsection{2. 현장실험 토양 시료}

토양 중 endosulfan의 분석은 Restek사의 QuEChERS kit (Pennsylvania, USA)를 사용하였으며, AOAC 2007 방법에 ${ }^{18)}$ 따라 토양 $50 \mathrm{~g}$ 에 magnesium sulfate $20 \mathrm{~g}$, sodium chloride $5 \mathrm{~g}$ 및 sodium citrate $5 \mathrm{~g}$ 을 첨가한 다음 acetone $150 \mathrm{~mL}$ 를 가하여 2회에 걸쳐 2시간 동안 $150 \mathrm{rpm}$ 으로 진탕 및 추 출하였다. Acetone 추출액을 여과 후 $40^{\circ} \mathrm{C}$ 에서 감압 농축하 고, acetonitrile $4 \mathrm{~mL}$ 를 가하여 용해하였다. 이 후 과정은
2.4.1에 기술한 방법과 같다.

\subsubsection{GC-ECD 분석 유효성 검증}

GC-ECD로 분석한 endosulfan 항목은 $\alpha$-endosulfan, $\beta$ -endosulfan, ether, diol, sulfate, lactone이다. 분석에 사용한 표준물질의 검량범위는 $0.0-10.0 \mu \mathrm{g} / \mathrm{mL}$ 이며, 표준물질 각각의 상관계수는 $\left(\mathrm{R}^{2}\right)$ a-endosulfan이 0.9997, ß-endosulfan이 0.9989, ether가 0.9991, diol이 0.9982, sulfate가 0.9989, lactone이 0.9993 으로 좋은 직진성을 보였다. 검출한계는 $\mathrm{S} / \mathrm{N}$ (signal to noise) 3 이상으로 하여 a-endosulfan, $\beta$-endosulfan, ether, diol, sulfate, lactone이 각각 0.008, 0.015, 0.017, 0.006, $0.020,0.012,0.020 \mu \mathrm{g} / \mathrm{mL}$ 로 확인되었다.

\section{5. 현장실험용 미생물의 배양}

유기염소계농약인 endosulfan 분해능이 우수한 2종의 균 주를 시험에 사용하였다. P. chrysosporium Y-2는 PDB 배지 를 사용하여 $400 \mathrm{~L}$ 대량배양장치에서 $25^{\circ} \mathrm{C}$ 의 온도로 72 시 간 배양하였다. 배양 종료 후 원심분리 $(3,000 \mathrm{rpm} / 10 \mathrm{~min})$ 하 여 cell을 분리하였고 균사를 homogenizing 하여 균질화시 켰으며, 다시 원심분리하여 분리한 cell의 습중량을 측정하 였다. S. sp. MJM14747은 BN (Barnnett's medium) 배지를 사용하여 $400 \mathrm{~L}$ 대량배양장치에서 $30^{\circ} \mathrm{C}$ 의 온도로 7 일간 배 양하였으며, 배양 종료 후 원심분리 $(3,000 \mathrm{rpm} / 10 \mathrm{~min})$ 하여 cell을 분리 및 습중량을 측정하였다. P. chrysosporium Y-2 및 S. sp. MJM14747은 습중량 기준으로 7:3 비율로 혼합하였 고, 혼합 총량 $5 \mathrm{~kg}$ 을 $50 \mathrm{~L}$ 의 멸균수에 풀어 균질화하였다.

\section{6. 복합미생물 담체화}

톱밥에 미생물을 담지시키기 위해서 원심분리하여 준비 한 복합미생물 cell에 멸균된 톱밥 $12 \mathrm{~kg}$ 을 균일하게 혼합하 였다. 톱밥에 흡수된 미생물 이외의 여액은 제거하였고, $25-28^{\circ} \mathrm{C}$ 의 온도에서 4 주간 방치시키며 자연 건조 및 미생물 의 포자 생성을 유도하였다. 본 연구에 사용된 톱밥의 양은 현장토양실험에 처리되는 토양의 부피 비율로 $(3 \mathrm{~m} \times 3 \mathrm{~m} \times$ 


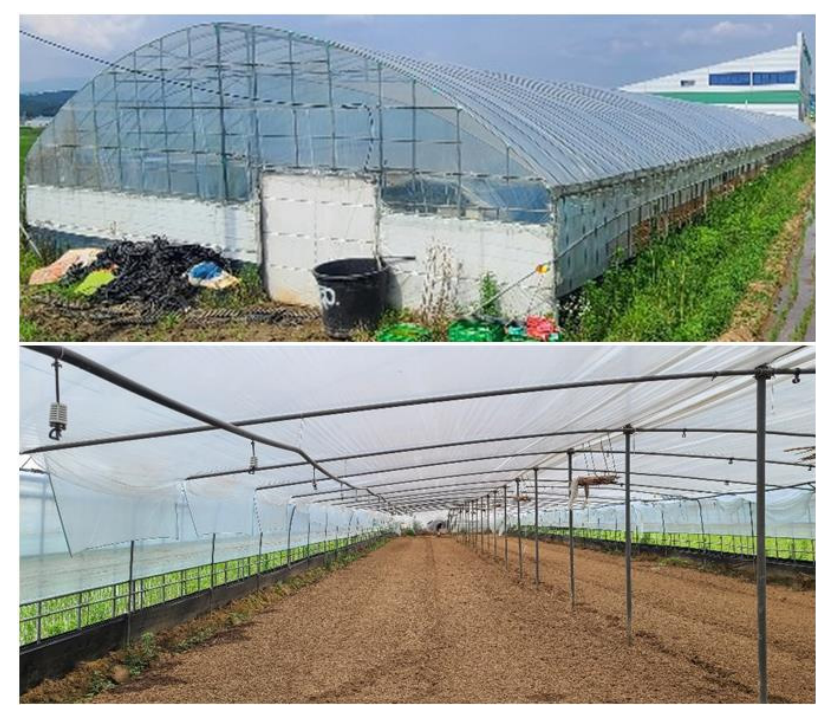

Fig. 1. Field experiment site located in Jeollanam-do province.

$0.3 \mathrm{~m})$ 계산 시 약 $2.2 \%$ 에 해당한다.

\section{7. 현장토양 시험 디자인}

최초 실험 디자인은 장소 및 토양 조건이 다르고, 실제 유기 염소계농약으로 오염된 토양에서 현장실험을 진행하려 하였 다. 그러나 시험포로 3 개월 이상 사용을 허락하고, endosulfan 으로 오염된 토양을 가진 농가를 찾기가 현실적으로 매우 어
려웠다. 그리고 섭외한 농가 토양 중의 endosulfan 농도가 0.4 $\mu \mathrm{g} / \mathrm{g}$ 으로 낮아 endosulfan을 인위적으로 오염시켜야 했으나 농가에서 실제 사용 중인 경작지였기 때문에 넓은 면적을 오 염시킬 수 없는 문제점이 있었다. 따라서, 대조구 및 실험구 site를 3 반복으로 설정하지 않고 하나씩 조성하여 다음과 같 이 현장실험을 진행하였다.

현장토양 시험은 Fig. 1과 같이 전라남도 화순군 도곡면 효산리 소재 밭 토양을 섭외하여 진행하였다. 노지 토양의 경우 비, 바람, 동물 및 기타 여러 외부 환경요인에 의한 시 험포의 파손이 우려되어 비닐하우스 내 토양을 선택하였다. 참고로, 섭외한 비닐하우스에서는 배추, 고추 및 토마토 등 의 채소류를 경작해오고 있었다. 토양시험에 사용되는 시험 포의 규모는 대조구 및 실험구 2 개로 각각 $3 \mathrm{~m} \times 3 \mathrm{~m}$ 의 동 일한 면적으로 조성하였다. 대조구 및 실험구에 각각 $35 \%$ 의 유제 $150 \mathrm{~mL}$ 를 $20 \mathrm{~L}$ 물에 희석 후 실험 면적을 $30 \mathrm{~cm}$ 깊이 로 파 모아놓은 훍에 분무하면서 유제가 토양 입자에 균일 하게 혼합되도록 소형 경작기를 이용하여 균질화시켰다.

\section{8. 복합미생물 처리}

대조구와 실험구의 조성 및 미생물 처리 과정은 Fig.2와 같다. 대조구에는 멸균 톱밥 $12 \mathrm{~kg}$ 을, 실험구에는 복합미생 물이 담지된 톱밥 $12 \mathrm{~kg}$ 각각 혼합하였다. 훍과 톱밥 그리 고 유제가 균일하게 혼합될 수 있도록 소형 경작기로 충분

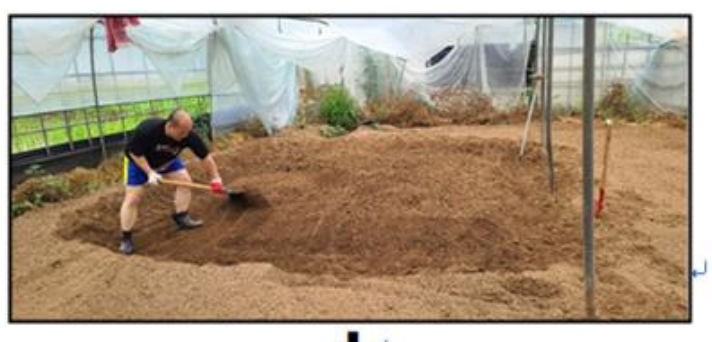

4

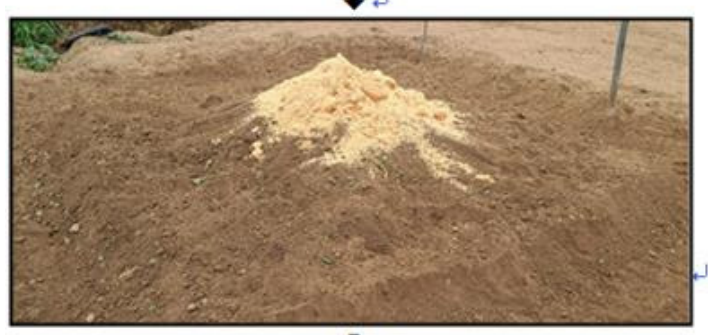

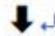

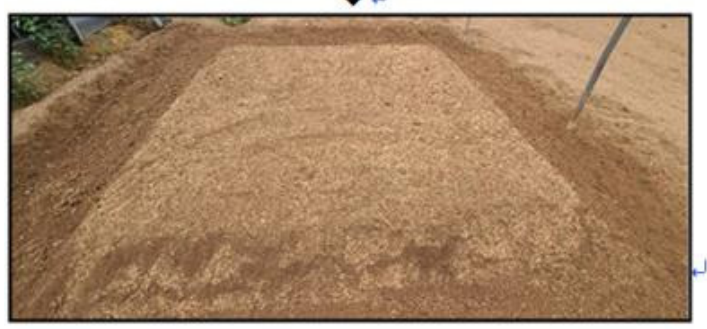

Control

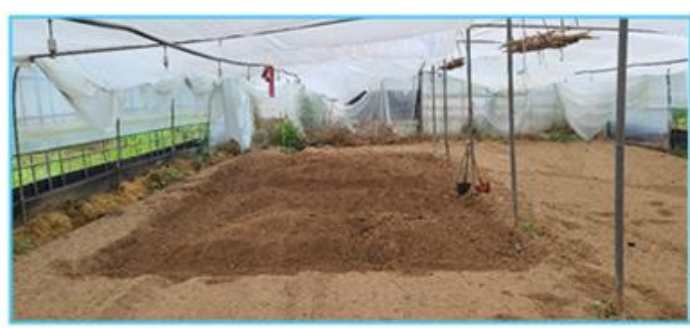

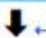

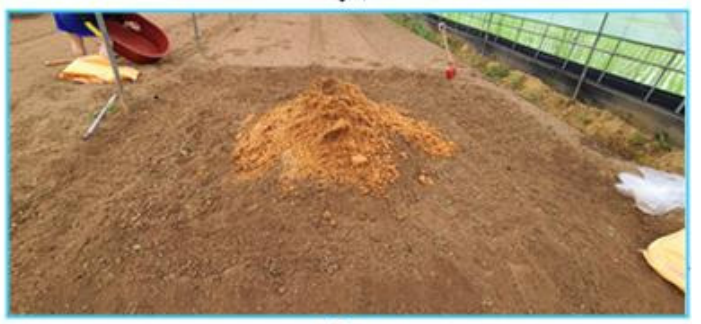

$\downarrow$

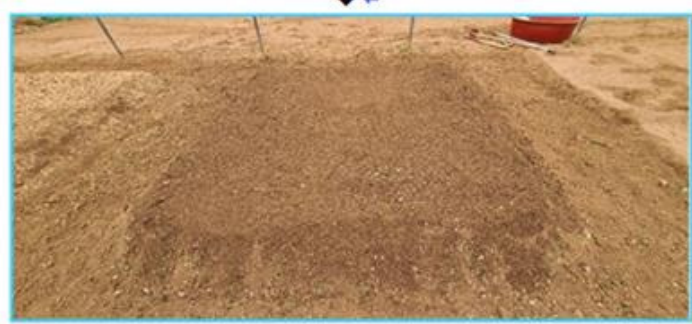

Microbial consortia treatment

Fig. 2. Treatment of endosulfan and microbial consortia in the experiment sites. 
히 섞는 과정을 반복하였다. 톱밥 혼합 작업 후 토양을 다시 평평하게 펼쳤고 그 위에 물 $50 \mathrm{~L}$ 를 추가로 분무하여 미생 물 생장에 적절한 함수율을 가질 수 있도록 하였다.

\section{9. 시험포 관리}

복합미생물 접종 후 30 일마다 대조구 및 실험구 토양을 $30 \mathrm{~cm}$ 깊이로 뒤엎어 토양 내외부의 미생물 분포를 골고루 분포시킴과 동시에 통기의 기회를 주어 미생물의 생장에 도 움이 되도록 하였다. 실험 기간인 7-10월 중 여름 장마 기간 을 제외하고 맑은 날에는 수분 증발이 빠르게 진행되어 2-3 일에 한 번씩 약 $50 \mathrm{~L}$ 의 물을 분무하였으며, 토양 표면으로 부터 $20 \mathrm{~cm}$ 내의 수분이 $70-80 \%$ 를 유지하도록 관리하였다. 실험 기간 내 토양의 온도는 최저 $28^{\circ} \mathrm{C}$, 최고 $53^{\circ} \mathrm{C}$, 평균 $37^{\circ} \mathrm{C}$ 였으며 일조량이 많은 날에는 비닐하우스 양옆을 열어 통풍 시키고 윗부분에는 그늘막을 설치하여 급격한 온도의 상승 을 막았다.

\subsection{0. 시료 샘플링 및 분석}

\subsection{1. 시료 채취방법}

분석용 토양 시료는 시료 채취기로 5 개 지점에서 $10 \mathrm{~cm}$ 깊이로 약 $100 \mathrm{~g}$ 채취 후 혼합하였으며, 이를 하나의 시료 로 사용하였다. 이 시료 채취 과정을 총 3 번 하여 3 반복 시 료로 하였으며, 각각의 시료 약 $500 \mathrm{~g}$ 은 음건 후 $2 \mathrm{~mm}$ 체 로 걸러 $\mathrm{GC}$ 분석을 위해 전처리하였다.

\subsection{2. 토양 16S rRNA metagenome 분석}

현장실험 토양에 endosulfan 분해용 미생물인 방선균 및 곰팡이를 접종하기 전에 원래 토양 내 서식하는 세균의 분
포도를 확인하기 위하여 $16 \mathrm{~S}$ rRNA metagenome 분석을 진 행하였다. 분석용 시료는 시료 채취기로 10 개 지점에서 10 $\mathrm{cm}$ 깊이로 약 $100 \mathrm{~g}$ 채취 후 균일하게 혼합하였으며, $2 \mathrm{~mm}$ 체로 걸러 토양 이외의 잡물을 제거하였다. 이후 (주)마크로 젠에 의뢰하여 토양 시료의 $16 \mathrm{~S}$ rRNA metagenome 분석을 진행하였다.

\subsection{3. 토양의 $\mathrm{pH}$ 및 입자크기}

토양 $5 \mathrm{~g}$ 을 $50 \mathrm{~mL}$ 비커에 취하고 증류수 $25 \mathrm{~mL}$ 를 넣어 유리막대로 저어주면서 1 시간 방치 후 $\mathrm{pH}$ 미터로 측정하였 다. 토양 입자 크기는 KS A 5101 표준망체 No. 4, No. 8, No. 16 , No. 30 , No. 50 , No. 100 을 사용하였고 각각의 기준 치수는 $4.75 \mathrm{~mm}, 2.36 \mathrm{~mm}, 1.18 \mathrm{~mm}, 600 \mu \mathrm{m}, 300 \mu \mathrm{m}, 150$ $\mu \mathrm{m}$ 이다. 건조된 토양 시료 일정량의 무게를 측정하고 가장 큰 크기부터 순차적으로 체가름 하여 전체 무게에 대한 각 각의 무게 비율로 토양 입자 크기별 분포율을 계산하였다.

\section{3. 결과 및 고찰}

\subsection{Endosulfan 분해능이 우수한 미생물의 선발}

방선균은 명지대학교가 국내 다수의 농경지 토양에서 230 종의 미생물을 분리하여, $100 \mathrm{mg} / \mathrm{L}$ endosulfan이 포함된 agar media에 접종 후 생장이 우수한 미생물 23종을 1차 선발 및 동일 농도 조건의 액상 배지에서 endosulfan 분해능이 가장 우수하였던 3종을 토양 실험에 사용하였다. ${ }^{19)}$ 곰팡이 및 효 모는 토양개량 용도로 유류 또는 중금속 오염 토양의 복원에 사용되는 자사보유 균주를 사용하였다. ${ }^{20,21)}$ 실험실 조건에서 토양 실험을 진행한 결과는 Fig. 3과 같다. 비교적 고농도의
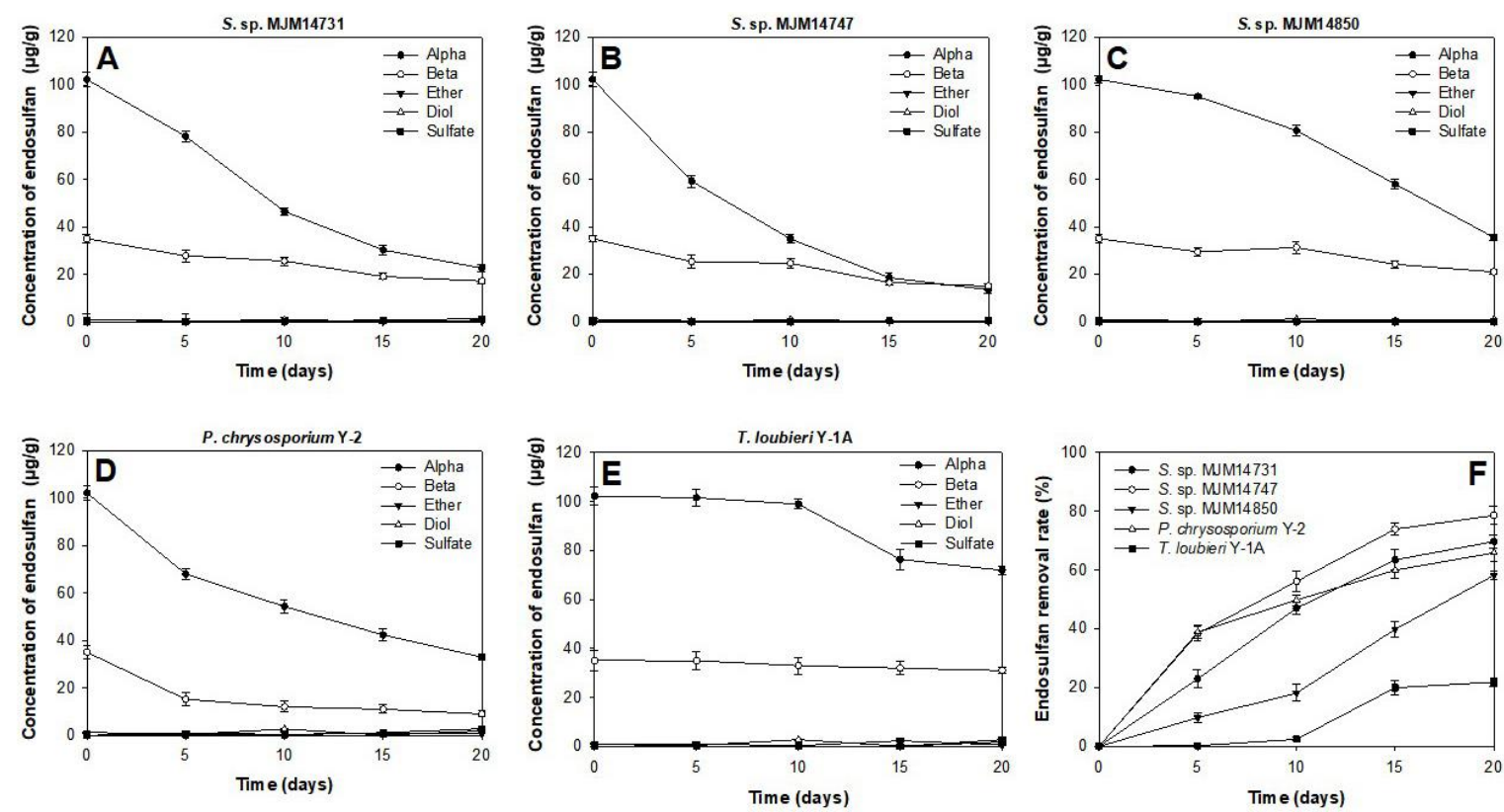

Fig. 3. Degradation of endosulfan by various microorganisms. 

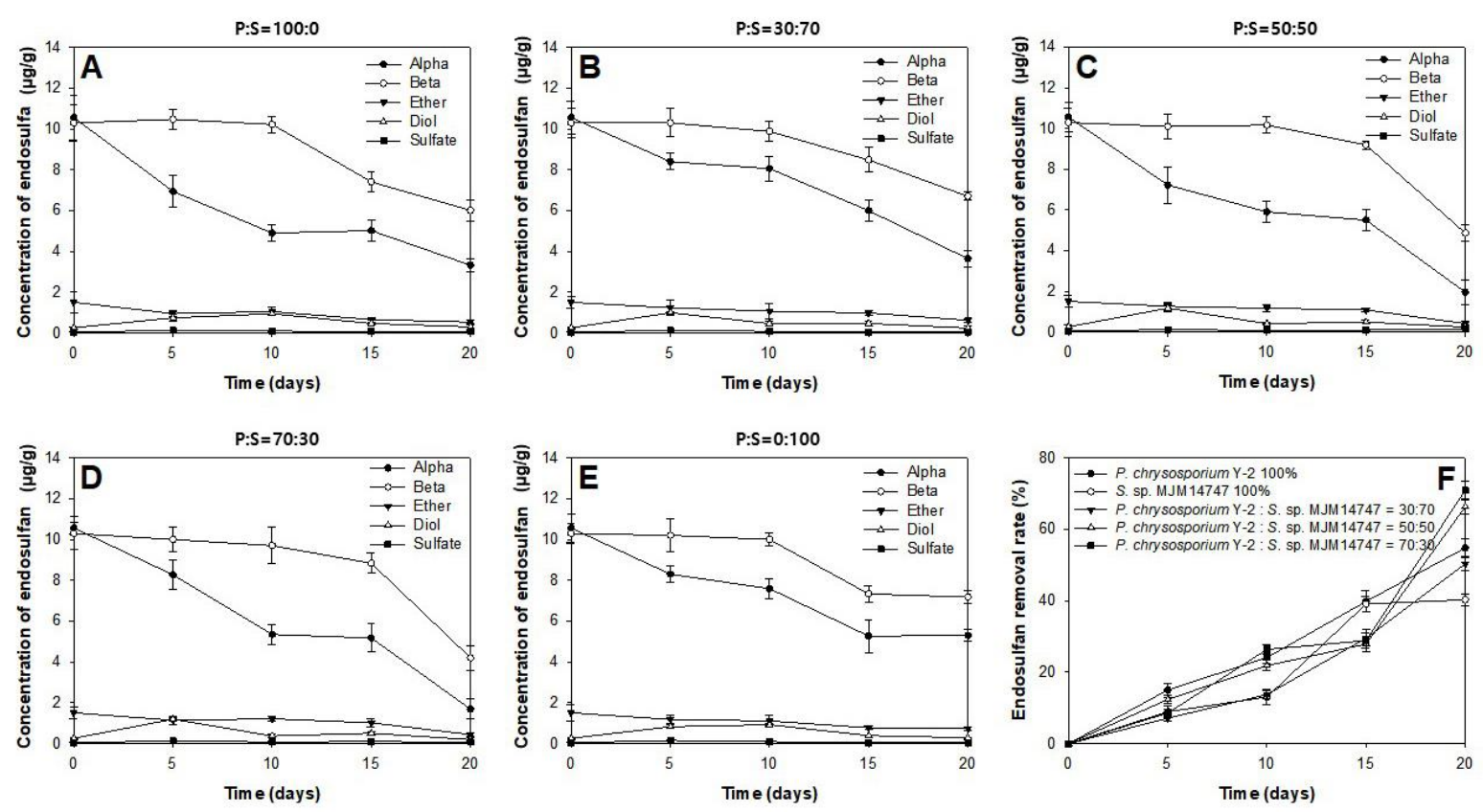

Fig. 4. Degradation of endosulfan by microbial consortia.

endosulfan $(138 \mu \mathrm{g} / \mathrm{g})$ 이 처리된 토양에서 배양 20 일 후 $S$ sp. MJM14747 균주가 78.6\%로 가장 높은 endosulfan 제거율 을 나타냈고(Fig. 3(B)), 다음으로 S. sp. MJM14731 (69.7\%, Fig.3(A)), P. chrysosporium Y-2 (65.8\%, Fig.3(D)) 및 S. sp. MJM14850 (58.2\%, Fig.3(C)) 순으로 높았다. 한편, 효모인 T. loubieri Y-1A는 21.9\% (Fig.3(F))의 제거율로 다른 미생물 에 비하여 2.7-3.5배 낮았다. Endosulfan의 주요 성분인 a -endosulfan의 제거율 또한 S. sp. MJM14747 균주가 $86.8 \%$ 로 가장 높았고, $\beta$-endosulfan의 제거율은 $57.1 \%$ 로 두 번째로 높 은 제거율을 보였다(Fig.3(B)). 다른 4종 미생물의 endosulfan 분해 경향과 다르게 P. chrysosporium Y-2의 a-endosulfan의 제거율은 $67.7 \%$ 였으나 $\beta$-endosulfan의 제거율은 $74.3 \%$ 로 전 체 미생물 중 가장 높아 분해속도가 비교적 느린 $\beta$-endosulfan 의 분해에 매우 효과적으로 작용한 것으로 확인되었다(Fig. 3(D)). 본 토양 실험결과로 총 endosulfan 및 $\mathrm{a}$-endosulfan의 제거율이 가장 높았던 $S$. sp. MJM14747와 $\beta$-endosulfan의 제거율이 가장 높았던 P. chrysosporium Y-2를 현장실험용 미 생물로 최종 선발하였다. 두 균주를 복합 적용 시 endosulfan 의 주요 성분인 $a$-endosulfan 및 $\beta$-endosulfan의 제거율이 가 장 이상적으로 증가할 것으로 예상되었다.

\section{2. 복합미생물의 endosulfan 분해능}

총 5종의 후보 미생물 중 고농도 endosulfan 토양 실험 을 통하여 방선균 1종(S. sp. MJM14747) 및 곰팡이 1종( $P$. chrysosporium Y-2)을 최종 선발하였으며, 두 미생물을 복합 적으로 적용 시 endosulfan 제거율에 어떠한 영향을 미치는 지에 대해 알아보기 위하여 두 미생물에 대한 혼합 비율을 달리하여 실험하였으며 그 결과는 Fig.4와 같다. 미생물 단
독 또는 일정 비율로 혼합하여 적용 시 P. chrysosporium Y-2와 S. sp. MJM14747의 비율이 70:30일 때 70.9\%로 가장 높은 endosulfan 제거율을 나타냈다(Fig. 4(D), (F)). 단독으 로 처리한 P. chrysosporium Y-2 및 S. sp. MJM14747의 endosulfan 제거율은 각각 $54.8 \%$ (Fig. 4(A)) 및 40.3\% (Fig. 4(E))로 확인되었으며, S. sp. MJM14747이 단독일 때 가장 낮았다. 곰팡이 및 방선균의 비율이 $30: 70$ 일 때 $50.3 \%$ (Fig.4(B)), 50:50일 때는 66.3\% (Fig. 4(C))로 전반적으로 $P$. chrysosporium Y-2의 비율이 증가할수록 endosulfan 제거율 또한 상승하는 추세를 보였다. Endosulfan의 주요 성분인 a -endosulfan 및 $\beta$-endosulfan의 제거율 또한 곰팡이 및 방선 균의 비율이 70:30일 때 각각 $84.0 \%$ 및 $59.2 \%$ 로 가장 높았 고 $(\beta / \mathrm{\alpha}=0.70)$, 다음으로는 $50: 50$ 일 때 $81.4 \%$ 및 $52.7 \%$ ( $\beta / \mathrm{a}$ $=0.65)$, 곰팡이 단독일 때 $68.5 \%$ 및 $41.7 \%(\beta / \mathrm{a}=0.61)$, $30: 70$ 일 때 $65.5 \%$ 및 $35 \%(\beta / \alpha=0.53)$, 마지막으로 방선균 단독일 때 $50.0 \%$ 및 $30.3 \%(\beta / \mathrm{a}=0.60)$ 순으로 나타났다. 동 일한 농도의 $a$-endosulfan 및 $\beta$-endosulfan 처리 조건에서 곰팡이의 비율이 증가할수록 $\beta$-endosulfan의 제거율 또한 증가하여 $\beta / \alpha$ 비율이 0.70 으로 가장 높아 P. chrysosporium $\mathrm{Y}-2$ 가 $\beta$-endosulfan의 제거에 주요하게 작용한 것으로 확인 되었다.

본 실험에 사용된 방선균은 명지대학교에서 미생물 230 종 을 $100 \mu \mathrm{g} / \mathrm{L}$ 의 고농도 endosulfan 존재하에서 스크리닝하여 그 중 endosulfan 분해능이 가장 우수하였던 균주를 최종적 으로 선발한 것이기 때문에 고농도 endosulfan에 대한 독성 저항성이 높은 것으로 판단되었다. 곰팡이와 방선균의 비교 실험에서, endosulfan의 농도가 $138 \mu \mathrm{g} / \mathrm{g}$ 인 조건에서는 $S$. sp. MJM14747의 endosulfan 제거율이 P. chrysosporium Y-2 


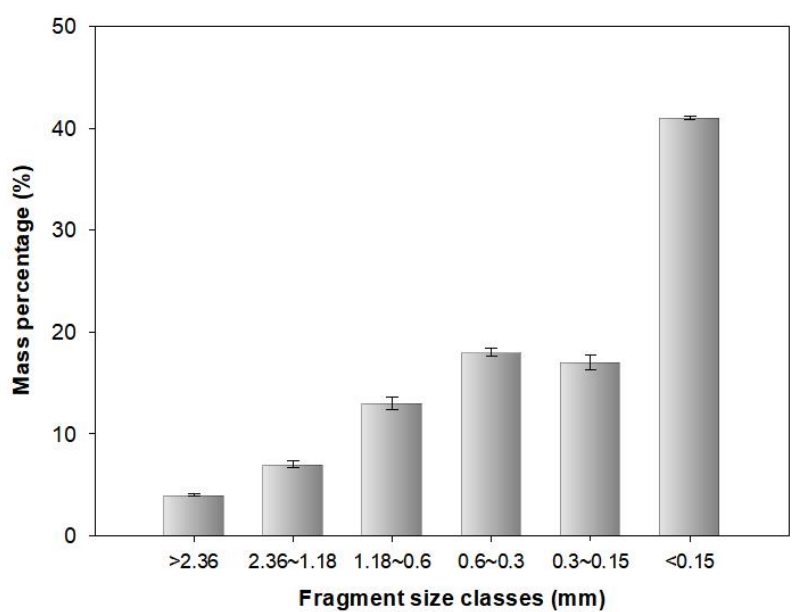

Fig. 5. The fragment size distribution of the soil.

보다 높았으나 저농도에서는 반대로 P. chrysosporium Y-2 의 제거율이 높은 것으로 나타나 역시 고농도 endosulfan에 대한 독성 저항성은 방선균이 곰팡이보다 높은 것으로 확인 되었으며, $20 \mu \mathrm{g} / \mathrm{g}$ 내외의 비교적 낮은 농도에서는 독성의 영향이 감소함에 따라 곰팡이의 endosulfan 제거율이 증가 한 것으로 판단되었다.

\section{3. 실험 전 현장토양 분석결과}

현장 시험 시작 전의 토양 입자크기 분포율은 Fig.5와 같 다. 입자의 크기가 $0.15 \mathrm{~mm}$ 이하의 세사, 미사 및 점토에 해당하는 부분은 $41 \%$ 를 차지하였고, 다음으로 $0.15-1.18$ $\mathrm{mm}$ 크기의 중사 및 굵은 모래에 해당하는 부분이 $48 \%$ 및 $2.0 \mathrm{~mm}$ 이상의 매우 굵은 모래에 해당하는 부분이 $11 \%$ 를 차지하였다. 이와 같은 토양 입자의 조성은 사질 토양에 가 까운 것으로 판단되었다. 사질 토양은 석영과 모래의 비율 이 높아 보수력은 약하지만 투수성이 좋아 무기질의 용탈이 잘 일어나고 통기성이 좋은 특성이 있어 방선균 및 곰팡이 와 같은 호기성 미생물의 생장에 좋은 환경인 것으로 판단
되었다. ${ }^{22)}$ 토양의 $\mathrm{pH}$ 는 6.83 으로 약산성을 나타내 이 또한 방선균 및 곰팡이의 생장에 적합하였다.

\section{4. 복합미생물 처리 후 토양의 잔류 endosulfan 분석결과}

현장토양 시험은 전남 화순군에 소재한 비닐하우스를 시 험포로 하여 $3 \mathrm{~m} \times 3 \mathrm{~m}$ 면적으로 대조구(Control)와 복합미 생물을 처리한(Microbial consortia treatment) 실험구로 나누 어 실험을 진행하였다. 대조구는 endosulfan 유제와 멸균 톱 밥을 혼합한 토양이며, 실험구는 endosulfan 유제와 복합미 생물이 담지된 톱밥을 혼합한 토양이다. Endosulfan 유제를 처리하기 전 현장토양의 endosulfan 농도는 약 $0.4 \mu \mathrm{g} / \mathrm{g}$ 으로 확인되었으며, 유제 및 복합미생물 처리 이후 총 100 일간 실험을 진행하며 endosulfan의 분해율을 분석하였다.

대조구 및 실험구의 시간에 따른 endosulfan 분해 양상은 Fig. 6 및 Fig.7에, 제거율은 Fig.8에 나타내었다. 총 100일간 의 실험기간 동안 대조구의 endosulfan의 제거율은 $54.4 \%$ 로 나타났다(Fig.8). 두 개의 이성질체 중 a-endosulfan은 60 일째 에 $50.9 \%$ 의 제거율을 보였고, $\beta$-endosulfan은 $22.9 \%$ 의 제거 율을 보였다. 일반적으로 토양에서의 endosulfan 평균 반감기 는 50일이며 a-endosulfan은 35일, $\beta$-endosulfan은 150 일의 반감기를 가지는 것으로 보고되고 있다. ${ }^{23)}$ 본 현장실험 결과 에서, 대조구의 a-endosulfan 반감기는 약 60일, $\beta$-endosulfan 은 150 일 내외일 것으로 추측되었고, 보고된 평균 반감기보 다 비교적 낮은 제거율을 나타내는 것으로 확인되었다. 대조 구에 별도의 미생물을 처리하지 않았음에도 endosulfan 제 거율이 확인되는 이유는 대조구 토양에 정착되어있는 토착 미생물들에 의한 endosulfan 분해 효과라고 판단되었다. 세 균 16S rRNA metagenome abundance 비율 분석결과에서 확 인할 수 있듯이 'Uncultured' 결과를 제외하면 Bacillus 속이 $8.96 \%$ 로 가장 많은 부분을 차지하고 있었고, 다음으로는 Nocardioides (5.40\%), Gaiella (4.76\%), Sphingomonas (4.62\%), Thioprofundum (2.83\%), Streptomyces (2.71\%),
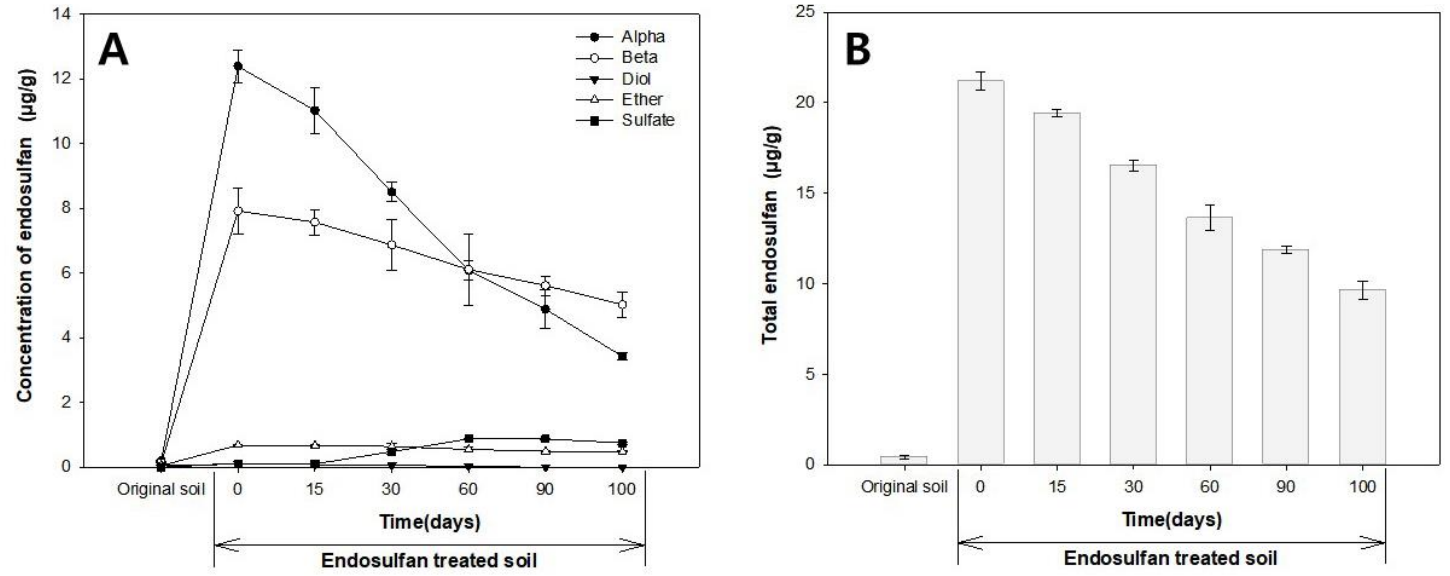

Fig. 6. Degradation of endosulfan in the control site. 

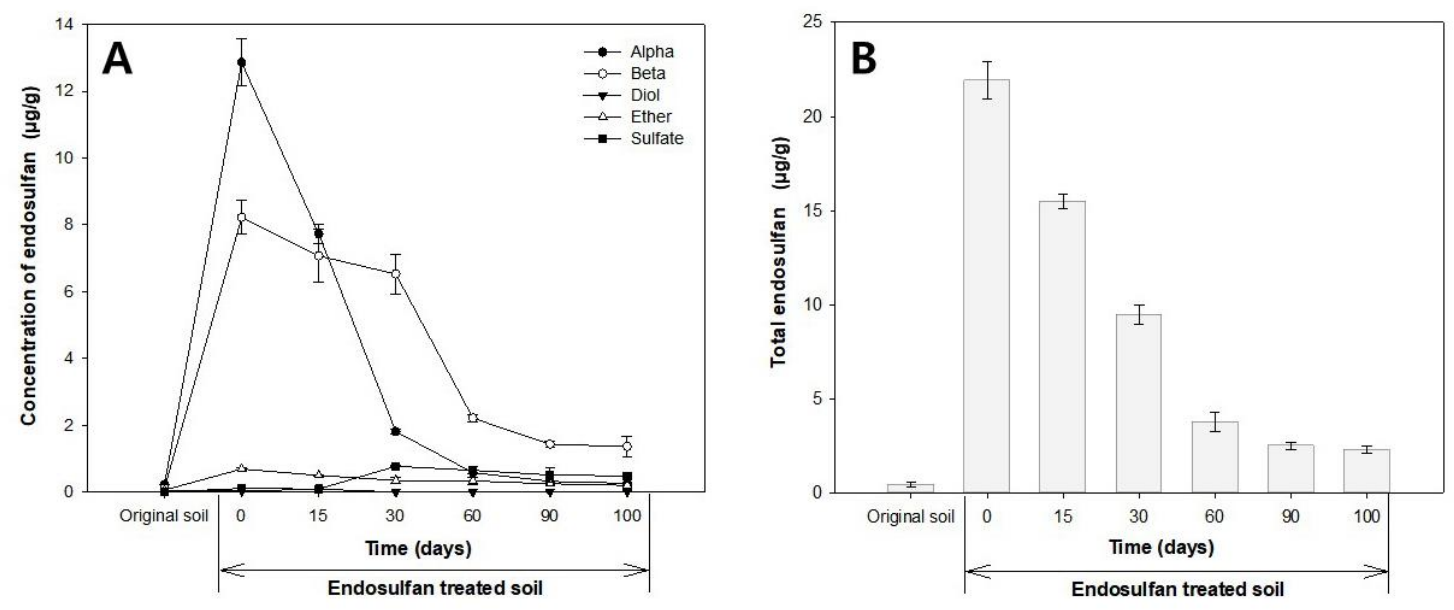

Fig. 7. Degradation of endosulfan in microbial consortia treated site.

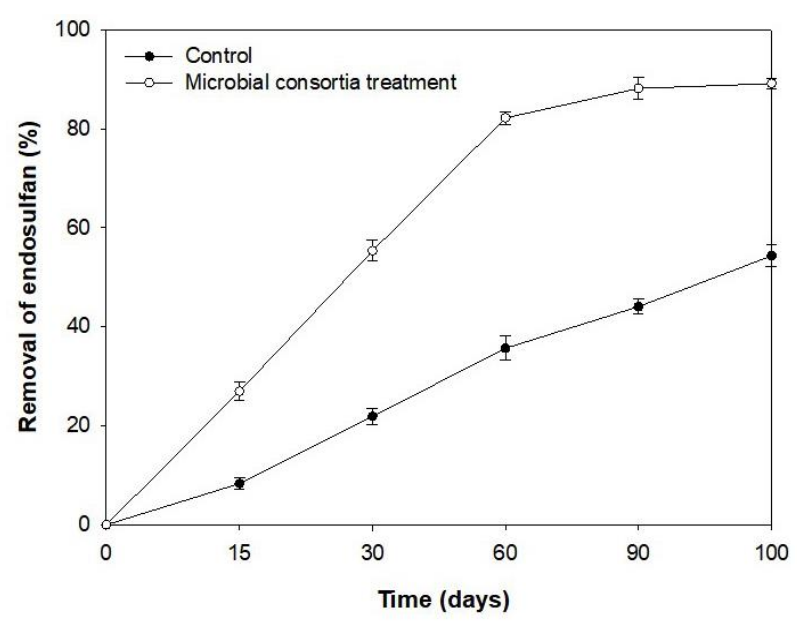

Fig. 8. The percentage removal of endosulfan in soil.

Lysobacter (2.68\%), Solirubrobacter (2.61\%), Adhaeribacter (2.40\%), Ohtaekwangia (2.29\%), Hydrogenispora (2.27\%), Sphingosinicella (2.23\%), Blastococcus (1.99\%) 및 기타 수십 속의 미생물이 분포하고 있었다(Abundance 비율이 $0.9 \%$ 이하로 낮은 수십 속의 미생물은 그래프에 표시하지 않음). Endosulfan의 생물학적 분해에 대한 연구는 다수 보고되고 있고 ${ }^{24-26)}$ 특히, Fig. 9의 결과와 같이 토양 중 높은 비율을 차지하는 Bacillus 속 ${ }^{27,28)}$, Nocardioides 속 ${ }^{29)}$, Sphingomonas 속 $^{30-32)}$, Streptomyces 속 ${ }^{33-36)}$ 에 대한 연구가 보고되었다.

복합미생물을 처리한 실험구는 Fig. 10과 같이 미생물이 토양에 잘 정착한 것을 확인할 수 있었다. Endosulfan 제거 율은 복합미생물 처리 100 일째에 $89.5 \%$ 로 대조구와 비교 시 1.6배 높은 제거율을 나타냈다. 실험 60 일째에 a-endosulfan 은 $95.5 \%$ 의 매우 높은 제거율을 보였고, $\beta$-endosulfan 또한 $73.1 \%$ 로 높았다. 두 이성질체의 예상 반감기는 각각 20 일 및 50 일로 추측되었으며 복합미생물을 처리하지 않은 대조구에 비하여 a-endosulfan은 1.8배, $\beta$-endosulfan은 3.6배 높은 제 거율을 나타내는 것으로 확인되었다.

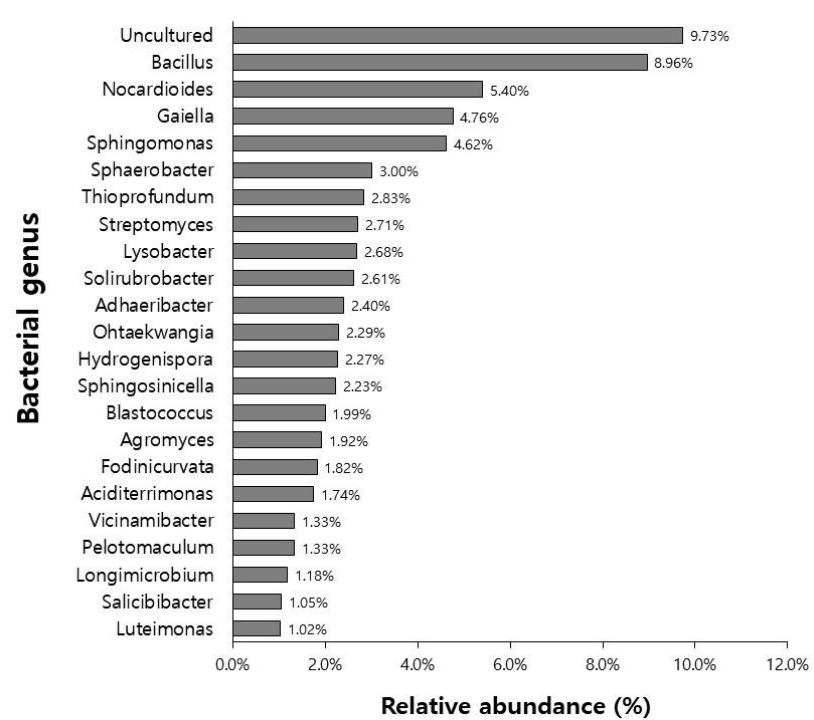

Fig. 9. Relative bacterial abundance in original field soil.

Endosulfan의 분해 과정 중 생성되는 endosulfan sulfate는 그 독성이 $\beta$-endosulfan보다 크며 분해속도 또한 매우 느린 것으로 알려져 있다. ${ }^{3)}$ 본 현장실험 결과에서는 대조구 및 실험구 모두 30 일이 경과 되는 시점부터 endosulfan sulfate 의 농도가 증가하였으나 대조구의 경우 60 일째 최대로 생 성 및 100 일까지 최대 농도인 시점을 기준으로 제거율이 $13.8 \%$ 로 미미한 반면 복합미생물을 처리한 실험구의 경우 30 일째 $0.77 \mu \mathrm{g} / \mathrm{g}$ 으로 최대 생성량을 보이다가 60 일 이후 제거율이 지속적으로 증가하여 100 일이 경과한 시점에는 최대 농도일 때와 비교하여 약 $37.6 \%$ 가 제거된 것으로 확 인되었다. 이는 대조구보다 2.7 배 높은 수치로 분해 생성물 에 의한 2차 오염이 대폭 감소된 것으로 확인되었다. 한편, 독성이 거의 없는 것으로 보고된 ${ }^{20-37)}$ endosulfan ether는 대 조구에서 시간이 경과함에 따라 낮은 제거율을 보이며 감소 하다가 100 일 째에는 약 $29.4 \%$ 분해되었다. 실험구에서 endosulfan ether는 대조구보다 빠른 감소를 보였으며 100 일 


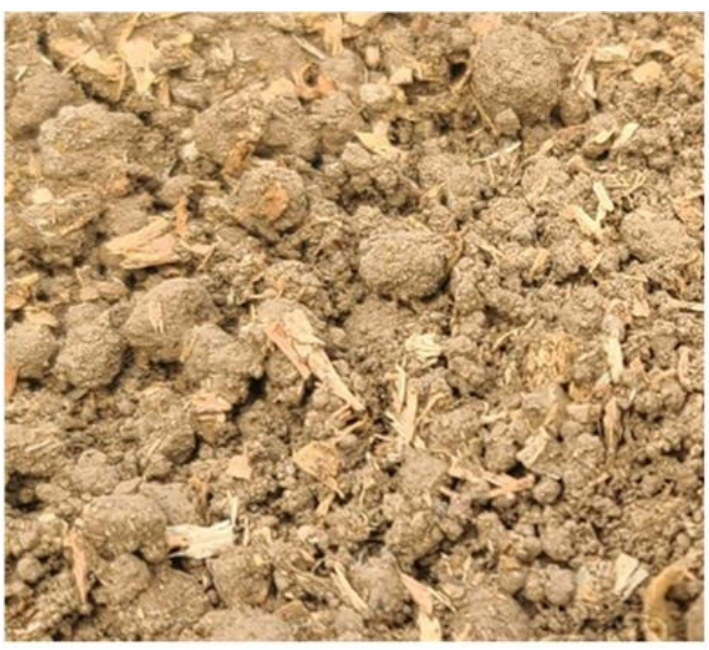

Control

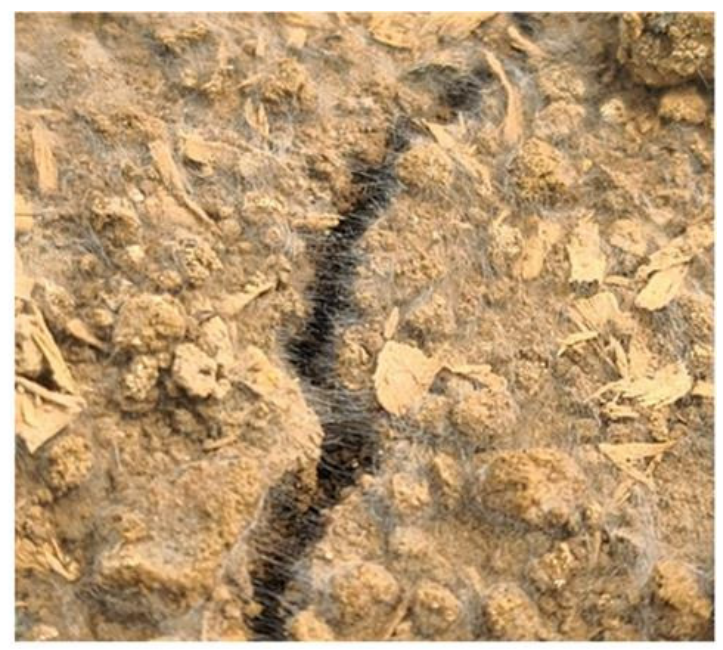

Microbial consortia treatment

Fig. 10. Comparison of microbial consortia treated and untreated soils.

째에는 $71 \%$ 의 제거율을 나타냈다. 기타 endosulfan 분해 하 위 생성 물질로서 endosulfan diol은 매우 낮은 농도로 변화 가 미미하였다.

유기염소계농약의 생물학적 처리와 관련된 연구로 Fuentes 등 ${ }^{33,35)}$ 은 Streptomyces sp. A5 균주를 사용하여 lindane, $\gamma$ -chlordane, methoxychlor에 대한 액상 분해실험을 진행한 결 과 $2 \mathrm{mg} / \mathrm{L}$ 의 농도에서 세 가지 성분이 각각 $57.4 \%, 100.0 \%$ 및 $6.5 \%$ 제거되었다고 보고하였고, 유기염소계농약으로 오염 된 지역에서 분리한 Streptomyces spp. A6, A12, A14, M7을 컨소시엄 조건으로 $1.66 \mathrm{mg} / \mathrm{kg}$ 의 methoxychlor에 처리하여 토양 $(56.2 \%)$ 및 슬러리(45.6\%)에 적용하는 등의 연구를 진 행한 바 있다. Benimeli 등 ${ }^{34)}$ 은 chlordane, DDD, DDE, DDT, dieldrin, heptachlor, heptachlor epoxides, lindane 및 methoxychlor 농약에 대한 액상 배양실험으로 Streptomycetes 균주를 최종 선발 후 5.0-50.0 $\mu \mathrm{g} / \mathrm{L}$ 농도의 aldrin, lindane, chlordane 존재하에서 균주의 생장확인 및 농약 성분에 따라 약 40-70\%의 제거율을 나타냈다고 보고한 바 있다. Coelho-Moreira 등 $\left.{ }^{38}\right)$ 은 제초제 성분인 diuron $(30 \mu \mathrm{mol} / \mathrm{L})$ 을 P. chrysosporium 로 10 일간 액상 배양하여 $94 \%$ 의 제거율을 보였다고 보고하였고, Bumpus 등 ${ }^{39}$ 도 P. chrysosporium 을 이 용한 총 30 일간의 실험에서 살충제 성분인 DDT를 $50 \%$ 까지 제거하였다고 보고하였다. 한편, 본 연구와 같이 세균과 곰팡 이의 조합은 아니지만 비슷한 연구로 Mohanasrinivasan 등 ${ }^{40}$ 은 총 30일간의 토양 실험에서 세균 단독 처리에(70.4-81.6\%) 비해 복합적으로 세균을 처리한 토양이 $(82.5 \%)$ 가장 높은 endosulfan 제거율을 나타냈으며, 미생물의 복합 적용이 유기 염소계농약으로 오염된 토양의 생물학적 정화에 유용한 방법 이 될 수 있다고 보고하였다. 이처럼 Streptomyces spp. 및 $P$. chrysosporium과 관련된 다수의 연구가 진행 되었지만 복합미 생물제제를 실제 토양에 적용한 사례는 드물기 때문에 본 연 구 결과를 생물학적 정화방법의 실제 적용을 위한 기본 자료
로 활용 가능할 것으로 판단되었다.

\section{4. 결론}

1) 오염된 토양의 복원을 위한 친환경적인 방법으로 미생 물을 이용한 생물학적 정화방법이 주목받고 있으며, 본 연 구에서도 방선균과 곰팡이로 이루어진 복합미생물제제를 실제 농경지 토양에 적용하여 endosulfan으로 오염된 토양 을 복원하는 실험을 진행하였다. 복합미생물제제를 처리 시 대조구에 비하여 전체적으로 1.6 배 높은 endosulfan 제거율 을 확인하였고, 구체적으로는 $\alpha$-endosulfan 및 $\beta$-endosulfan 이 대조구에 비하여 각각 1.8 배 및 3.6배 높은 제거율을 나 타냈으며, 분해 시간이 많이 소요되는 $\beta$-endosulfan의 제거 율이 Phanerochaete chrysosporium Y-2의 사용으로 대폭 개 선되었다.

2) 복합미생물제제에 포함된 방선균 Streptomyces sp. $\mathrm{MJM} 14747$ 은 $100 \mu \mathrm{g} / \mathrm{g}$ 내외의 고농도 endosulfan 조건에 서도 생존 및 분해력이 유지되었고, 곰팡이 Phanerochaete chrysosporium Y-2 또한 독성이 강한 유류 및 중금속 분해용 미생물로 사용되고 있어 유기염소계 농약으로 오염된 국내외 농경지 정화뿐만 아니라 전반적인 환경정화 사업에도 활용 이 가능할 것으로 기대된다.

\section{Acknowledgement}

본 성과물은 농촌진흥청 연구사업(세부과제번호: PJ01313302) 의 지원에 의해 이루어진 것임.

\section{References}

1. M. Kumar, C. V. Lakshmi, S. Khanna, Biodegradation and bioremediation of endosulfan contaminated soil, Bioresour. 
Technol., 99(8), 3116-3122(2008).

2. T. Siddique, B. C. Okeke, M. Arshad, W. T. Jr. Frankenberger, Enrichment and isolation of endosulfan-degrading microorganisms, J. Environ. Qual., 32(1), 47-54(2003).

3. D. M. R. Rao, A. S. Murty, Persistence of endosulfan in soils, J. Agric. Food Chem., 28(6), 1099-1101(1980).

4. J. Weber, C. J. Halsall, D. Muir, C. Teixeira, J. Small, K. Solomon, M. Hermanson, H. Hung, T. Bidleman, Endosulfan, a global pesticide: a review of its fate in the environment and occurrence in the Arctic, Sci. Total Environ., 408(15), 2966-2984(2010).

5. A. D. Morris, D. C. G. Muir, K. R. Solomon, R. J. Letcher, M. A. McKinney, A. T. Fisk, B. C. McMeans, G. T. Tomy, C. Teixeira, X. Wang, M. Duric, Current-use pesticides in seawater and their bioaccumulation in polar bear-ringed seal food chains of the Canadian Arctic, Environ. Toxicol. Chem., 35(7), 1695-1707(2016).

6. J.-H. Ahn, I. C. Park, W.-G. Kim, B.-H. Han, J. You, Effect of an organochlorine insecticide, endosulfan on soil bacteria community as evaluated by $16 \mathrm{~S}$ rRNA gene analysis, Korean J. Pestic. Sci., 21(1), 1-8(2017).

7. B.-J. Park, B.-M. Lee, C.-S. Kim, K.-H. Park, S.-W. Park, H.-Y. Kwon, J.-H. Kim, G.-H. Choi, S.-J. Lim, Long-term monitoring of pesticide residues in arable soils in Korea, Korean J. Pestic. Sci., 17(4), 283-292(2013).

8. A. Brinati, J. M. Oliveira, V. S. Oliveira, M. S. Barros, B. M. Carvalho, L. S. Oliveira, M. E. L. Queiroz, S. L. P. Matta, M. B. Freitas, Low, chronic exposure to endosulfan induces bioaccumulation and decreased carcass total fatty acids in neotropical fruit bats, Bull. Environ. Contam. Toxicol., 97(5), 626-631(2016).

9. C. Zhang, D. Wu, H. Ren, Bioremediation of oil contaminated soil using agricultural wastes via microbial consortium, Sci. Rep., 10(1), 9188(2020).

10. P. Agamuthu, Y. S. Tan, S. H. Fauziah, Bioremediation of hydrocarbon contaminated soil using selected organic wastes, Procedia Environ. Sci., 18, 694-702(2013).

11. R. M. Hesnawi, F. S. Mogadami, Bioremediation of Libyan crude oil-contaminated soil under mesophilic and thermophilic conditions, APCBEE Proc., 5, 82-87(2013).

12. J.-H. Shin, Y.-Y. Kwak, W.-C. Kim, J.-H. So, H.-S. Shin, J.-W. Park, T.-H. Kim, J.-E. Kim, I.-K. Rhee, Isolation of endosulfan degrading bacteria and their degradation characteristics, Korean J. Environ. Agric., 27(3), 292-297(2008).

13. M.-S. Jo, J.-B. Lee, J.-E. Kim, H.-Y. Sohn, C.-P. Jeon, C.-S. Choi, G.-S. Kwon, Biodegradation of endosulfan by Klebsiella oxytoca KE-8 immobilized on activated carbon, Korean J. Environ. Agric., 29(2), 176-183(2010).

14. A. E. S. A. Ishag, A. O. Abdelbagi, A. M. A. Hammad, E. A. E. Elsheikh, O. E. Elsaid, J.-H. Hur, Biodegradation of endosulfan and pendimethalin by three strains of bacteria isolated from pesticides-polluted soils in the Sudan, Appl. Biol. Chem., 60(3), 287-297(2017).

15. H. M. Shivaramaiah, I. R. Kennedy, Biodegradation of endosulfan by a soil bacterium, J. Environ. Sci. Health, Part
B, 41(6), 895-905(2006).

16. G.-S. Kwon, J.-E. Kim, T.-K. Kim, H.-Y. Sohn, S.-C. Koh, K.-S. Shin, D.-G. Kim, Klebsiella pneumoniae KE-1 degrades endosulfan without formation of the toxic metabolite, endosulfan sulfate, FEMS Microbiol. Lett., 215(2), 255-259(2002).

17. T. Siddique, B. C. Okeke, M. Arshad, W. T. Jr. Frankenberger, Enrichment and isolation of endosulfan-degrading microorganisms, J. Environ. Qual., 32(1), 47-54(2003).

18. S.-J. Lim, Y.-T. Oh, J.-H. Ro, S.-Y. Kim, H.-G. Joo, M.-H. Lee, H.-I. Yoon, G.-H. Choi, S.-H. Ryu, B.-J. Park, Exposure assessment of pesticide-orginated persistent organic pollutants in paddy and upland soils in Korea, Korean J. Environ. Agric., 36(3), 211-216(2017).

19. M.-J. Cho, J.-W. Suh, J. Cheng, Biodegradation of organochlorine pesticides by Actinomycetes, in Proceedings of the International Meeting of the Federation of Korean Microbiological Societies, FKMS, Seoul, pp. 24(2018).

20. COENBIO CO. Ltd., National Institute of Forest Science, Soil improver with white-rot fungi and methods of using thereof for plant restoration and recover of heavy metals contaminated soil around abandoned mine area, KR100903666B1, filed March 28(2006), and June 11(2009).

21. K.-J. Yum, Bioremediation method of contaminated soil, KR100397540B1, filed June 26(2000), and August 28(2003).

22. B.-K. Ahn, H.-J. Kim, S.-S. Han, Y.-H. Lee, J.-H. Lee, Response of microbial distribution to soil properties of orchard fields in Jeonbuk area, Korean J. Soil Sci. Fert., 44(5), 696-701(2011).

23. R. D. Wauchope, T. M. Buttler, A. G. Hornsby, P. W. M. Augustijn Beckers, J. P. Burt, The SCS/ARS/CES pesticide properties database for environmental decision-making, Rev. Environ. Contam. Toxicol., 123, 1-157(1992).

24. T. D. Sutherland, I. Horne, R. L. Harcourt, R. J. Russell, J. G. Oakeshott, Isolation and characterization of a Mycobacterium strain that metabolizes the insecticide endosulfan, J. Appl. Microbiol., 93(3), 380-389(2002).

25. T. D. Sutherland, I. Horne, R. J. Russell, J. G. Oakeshott, Gene cloning and molecular characterization of a two-enzyme system catalyzing the oxidative detoxification of beta-endosulfan, Appl. Environ. Microbiol., 68(12), 6237-6245(2002).

26. S. Hussain, M. Arshad, M. Saleem, A. Khalid, Biodegradation of $\alpha$ - and $\beta$-endosulfan by soil bacteria, Biodegradation, 18, 731-740(2007).

27. A. Kumar, N. Bhoot, I. Soni, P. J. John, Isolation and characterization of a Bacillus subtilis strain that degrades endosulfan and endosulfan sulfate, 3 Biotech., 4(5), 467-475 (2014).

28. K. S. Ahmad, Remedial potential of bacterial and fungal strains (Bacillus subtilis, Aspergillus niger, Aspergillus flavus and Penicillium chrysogenum) against organochlorine insecticide endosulfan, Folia Microbiol., 65, 801-810(2020).

29. K. Ito, K. Takagi, R. Kataoka, H. Kiyota, Biochemical characterization of $\mathrm{NADH}: \mathrm{FMN}$ oxidoreductase HcbA3 
from Nocardioides sp. PD653 in catalyzing aerobic HCB dechlorination, J. Pestic. Sci., 45(3), 125-131(2020).

30. A. Bilgin, S. L. Sanin, Isolation and identification of endosulfan degrading native bacterial consortium from agricultural soils, Waste Biomass Valorization, 11, 3303-3313(2020).

31. F. B. Yu, S. D. Shan, L. P. Luo, L. B. Guan, H. Qin, Isolation and characterization of a Sphingomonas sp. strain F-7 degrading fenvalerate and its use in bioremediation of contaminated soil, J. Environ. Sci. Health, Part B, 48(3), 198-207(2013).

32. M. K. Javaid, M. Ashiq, M. Tahir, Potential of biological agents in decontamination of agricultural soil, Scientifica, 2016, 1598325(2016).

33. M. S. Fuentes, P. E. Sineli, S. Pons, A. M. LeBlanc, C. S. Benimeli, R. T. Hill, S. A. Cuozzo, Study of the removal of a pesticides mixture by a Streptomyces strain and their effect on the cytotoxicity of treated systems, J. Environ. Chem. Eng., 6(6), 6836-6843(2018).

34. C. S. Benimeli, M. J. Amoroso, A. P. Chaile, G. R. Castro, Isolation of four aquatic streptomycetes strains capable of growth on organochlorine pesticides, Bioresour. Technol., 89(2), 133-138(2003).

35. M. S. Fuentes, A. Alvarez, J. M. Saez, C. S. Benimeli, M. J. Amoroso, Methoxychlor bioremediation by defined consortium of environmental Streptomyces strains, Int. J. Environ. Sci. Technol., 11, 1147-1156(2014).

36. T. Singh, D. K. Singh, Phytoremediation of organochlorine pesticides: concept, method, and recent developments, Int. J. Phytorem., 19(9), 834-843(2017).

37. W. W. Barnes, G. W. Ware, The absorption and metabolism of $\mathrm{C}^{14}$-labeled endosulfan in the house fly, J. Econ. Entomol., 58(2), 286-291(1965).

38. J. S. Coelho-Moreira, A. Bracht, A. C. S. Souza, R. F. Oliveira, A. B. Sa-Nakanishi, C. G. M. Souza, R. M. Peralta,
Degradation of diuron by Phanerochaete chrysosporium: role of ligninolytic enzymes and cytochrome P450, BioMed Res. Int., 2013, 251354(2013).

39. J. A. Bumpus, S. D. Aust, Biodegradation of DDT [1,1,1-trichloro-2,2-bis(4-chlorophenyl)ethane] by the white rot fungus Phanerochaete chrysosporium, Appl. Environ. Microbiol., 53(9), 2001-2008(1987).

40. V. Mohanasrinivasan, V. Suganthi, E. Selvarajan, C. Subathra Devi, E. Ajith, N. P. Muhammed Farhan, G. Sreeram, Bioremediation of endosulfan contaminated soil, Res. J. Chem. Environ., 17(11), 93-101(2013).

\section{Authors}

\section{Chan-Ho Park}

Coenbio Co., Ltd., Senior Researcher, ORCID 지 0000-0001-51647080

\section{Joo-Young Lee}

Coenbio Co., Ltd., General Manager, ORCID (1) 0000-0002-74578513

\section{Min-Ji Cho}

Department of Interdisciplinary Program of Biomodulation, Myongji University, Researcher, ORCID (D) 0000-0001-7165-5571

\section{Jinhua Cheng}

Center for Neutraceutical and Pharmaceutical Materials, Myongji University, Professor, ORCID(D) 0000-0001-6172-6882

\section{Kyu-Jin Yum}

Coenbio Co., Ltd., CEO, ORCID(D) 0000-0002-8315-021X 